\title{
Oppilaiden tuen tarpeet luonnontieteiden opetuksessa opettajaopiskelijoiden näkökulmasta
}

\author{
Kari Sormunen ${ }^{1}$, Anu Hartikainen-Ahia ${ }^{1}$ ja Teija Koskela ${ }^{2}$ \\ ${ }^{1}$ Itä-Suomen yliopisto \\ ${ }^{2}$ Turun yliopisto
}

Oppilaiden diversiteetti on inkluusioajattelun lähtökohta. Opettaja tarvitsee tietoja ja taitoja diversiteetin havaitsemiseen ja oppilaiden tukemiseen. Tutkimuksessa selvitämme, millaisia ennakkokäsityksiä opettajaopiskelijoilla on luonnontieteiden opetukseen liittyvistä tuen tarpeista. Käsityksiä kartoitettiin e-kyselyllä monialaisten opintojen luonnontieteiden opintojaksolla vuosina 2015-2018. Kyselyyn vastasi 491 luokan- ja erityisluokanopettajaopiskelijaa, joista tutkimusluvan antoi 468. Aineisto analysoitiin sisällönanalyysillä. Enemmistö opiskelijoista tarkasteli oppilaiden diversiteettiä ongelmakeskeisesti, jolloin tuki nähtiin ratkaisuna diagnosoituun oppimisvaikeuteen. Opettajaopiskelijat käsittelivät oppilaiden tuen tarvetta myös oppiaineiden sisältöihin ja opetustapahtumaan liittyen. Luonnontieteiden opetustilanteet tulisi rakentaa diversiteettia huomioivaksi, jolloin diversiteetti-käsite kattaa kaikki perusopetuksen oppilaat monipuolisesti ymmärrettyinä yksilöinä.

Artikkelin tiedot

LUMAT General Issue Vol 9 No 1 (2021), 126-148

Lähetetty 12. joulukuuta 2020 Hyväksytty 2. maaliskuuta 2021 Julkaistu 15. maaliskuuta 2021

Sivuja: 23

Lähteitä: 73

Yhteydenotot:

kari.sormunen@uef.fi

https://doi.org/10.31129/

LUMAT.9.1.1467

Asiasanat: inkluusio, oppimisen tuki, opettajankoulutus, luonnontieteiden opetus, ympäristöoppi

\section{Pupils needs for support in science education: Teacher students' perceptions}

Student diversity is the starting point for inclusive thinking. The teacher needs knowledge and skills to detect diversity and support students. In this study, we will investigate what kinds of preconceptions students have about the need for support in science education. Perceptions were surveyed in an electronic questionnaire during the 2015-2018 Interdisciplinary Studies in Natural Sciences. Totally, 491 class and special class teacher students, of whom 468 were granted research permission, answered the questionnaire. The data was analysed by content analysis. Most students looked at student diversity in a problem-oriented manner and support was seen as a solution to diagnosed learning disability. Teacher students also looked at the need for support in terms of subject content and teaching activities. Science teaching situations should be built with diversity in mind, so that the concept of diversity includes all students in basic education as diverse individuals.

Keywords: inclusion, support in learning, teacher education, science education, environmental studies 
Perusopetuksen opetussuunnitelman perusteet edellyttävät inkluusioperiaatteiden huomioimista koulutyön kehittämisessä (Opetushallitus 2014, s. 8). Inklusiivinen kasvatus on valittu myös koulutuksen kansainvälisten kehittämislinjausten tavoitteeksi (European Agency for Special Needs and Inclusive Education 2014; UNESCO, 2015). Inkluusio määritellään kuitenkin eri yhteyksissä eri tavoin. Kapeimmillaan inkluusiokäsite kohdentuu oppilaisiin, joilla on diagnosoituja oppimisvaikeuksia, tai se voi asteittain laajentua koskemaan vähemmistöjä ja erityisen haavoittuvassa asemassa olevia ryhmiä. Inkluusio nähdään myös diversiteettiä kunnioittavana yhteiskunnallisena periaatteena, jolloin koulutuksen yhteydessä lähtökohtana on kaikkien oppilaiden yhteinen koulu (Messiou \& Ainscow, 2020; Kiuppis \& Hausstätter, 2014). Inklusiivisella toimintakulttuurilla laajimmillaan viitataankin diversiteetin arvostamiseen kaiken koulutoiminnan lähtökohtana (Kugelmass, 2001). Tällöin inkluusio näyttäytyy koulujen halukkuutena vastata kaikkien oppijoiden opetuksesta heidän lähikoulussaan poistamalla oppimisen esteitä ja edistämällä kaikkien oppilaiden osallistumista kouluyhteisön toimintoihin yhdenvertaisesti (Ainscow, Booth, \& Dyson, 2006).

Oppijoiden diversiteetti on inklusiivisen kasvatusajattelun lähtökohta. Oppilaiden diversiteetti on haastava käsite, jota on jopa mahdoton määritellä yksiselitteisesti (Kousa \& Aksela, 2019; ks. myös Goethe \& Colina, 2018). Oppilasdiversiteettiin sisältyvät esimerkiksi oppilaan kulttuurinen, etninen, maantieteellinen ja sosioekonominen tausta, sukupuoli ja seksuaalinen orientaatio, kyvyt ja älykkyys, oppimisen ja kielen ongelmat, omat kokemukset, näkemykset ja asenteet sekä persoonallisuus (ks. esim. Goethe \& Colina, 2018; Wassel, Kerrigan, \& Hawrylak, 2018; Kousa \& Aksela, 2019). Yhteiskunnassamme diversiteetti onkin määrittymässä uudelleen entistä moniulotteisempana hyperdiversiteettinä (Doucerain, Dere, \& Ryder, 2013).

Oppilaan erityisyyksiin painottuvan näkökulman korostaminen on kuitenkin johtanut siihen, että käytännön opetustyössä yksittäisten oppilaiden monenlaiset tuentarpeet nimetään ja usein ne myös päällekkäistyvät (co-morbidity), jolloin oppilaasta muodostuva mielikuva rakentuu tuentarpeiden varaan ja jää yksipuoliseksi (Slee, 2001). Oppilaan määrittyessä vain omien tuentarpeidensa kautta voi syntyä kapeakatseisia stereotypioita (Zembylas \& Isenbarger, 2002), jotka rajoittavat oppilaan oppimismahdollisuuksia. Esimerkiksi useilla autismin kirjon oppilailla on havaittu erityislahjakkuutta, jolloin koulutyössä tuetaan sosiaalisten 
taitojen kehittymistä ja lahjakkuuden potentiaaleja. Foley-Nipcon, Assouline ja Colangelo (2013) ovat käsitteellistäneet ilmiötä englanninkieli-sellä termillä twice exeptional, jolloin oppilaalla voi olla yhtä aikaa tuen tarvetta ja lahjakkuutta; lahjakkuus yhdellä osa-alueella ei siis itsessään poista tuentarvetta muissa taidoissa. Oppimisen esteeksi voikin nousta joustamaton ja kaavamainen opetus, joka ei tunnista eikä tunnusta oppijoiden diversiteettiä (esim. Ainscow \& Sandill, 2010).

Koulun arkityössä yksittäisten ja erillisten tarpeiden huomioiminen yhden opettajan erillisillä toimenpiteillä voi olla haastavaa, ellei jopa mahdotonta. Siksi inklusiivisessa opetuksessa joustavan ja tukea tuottavan toimintakulttuurin rakentaminen on ensiarvoisen tärkeää. Jotta opettaja voi organisoida opetustaan oppilaiden tuentarpeita huomioivaksi, hänen tulee havaita oppilaidensa erityispiirteitä (Ainscow, Booth, \& Dyson, 2006) sekä kehittää opetuskäytänteitä oppilaiden ja opettajien yhteisprosessina (Messiou \& Ainscow, 2020). Oppilaiden tuen tarpeisiin vastaaminen tulee huomioida myös opettajien peruskoulutuksessa. Tutkimustehtävämme onkin selvittää, millaisia ennakkokäsityksiä opettajaopiskelijoilla on luonnontieteiden opetukseen liittyvistä tuen tarpeista.

\subsection{Opettajien ja opettajaopiskelijoiden käsityksiä erilaisista oppijoista luonnontieteiden opetuksessa}

Opettajat suhtautuvat inklusiiviseen opetukseen periaatteellisella tasolla myönteisemmin kuin käytännössä (Avramidis \& Norwich, 2002). Esimerkiksi suomalaisten opettajien (Savolainen, Engelbrecht, Nel, \& Malinen, 2012) ja irlantilaisten luokanopettajien (Young, McNamara, \& Coughlan, 2017) on havaittu suhtautuvan kriittisesti mahdollisuuksiinsa toteuttaa inklusiivista opetusta.

Kousan väitöstutkimuksen (2019) mukaan suomalaisilla kemianopettajilla on ongelmia havaita oppilaiden yksilöllisiä eroja, eikä heillä ole riittävästi tietämystä erilaisia oppilaita tukevista opetusmenetelmistä. Erityisen haastavina opettajat pitävät yksilöllisiä oppimisen haasteita, kuten oppilaiden eritasoisia oppimisen ongelmia, kulttuurisia eroja, kieli- ja käytösongelmia sekä oppilaiden välisiä konflikteja. Lisäksi oppilaiden motivaation puute ja negatiivinen suhtautuminen kemian opiskelua kohtaan nähdään problemaattisena. (Kousa \& Aksela, 2019; Kousa, 2019) Kemian opettajien mielestä heidän oppilaansa jakautuvatkin viiteen ryhmään: 1) hyvin menestyviin lahjakkaisiin oppilaisiin, 2) ei-motivoituneisiin heikosti menestyviin oppilaisiin, 3) heikosti menestyviin oppilaisiin, joilla on usein oppimisen tai kielen ongelmia, 4) ahkeriin oppilaisiin, jotka muistavat kaiken, mutta eivät 
välttämättä ymmärrä kemiaa sekä 5) käytännön töissä pärjääviin oppilaisiin, joilla on heikko käsitteellinen ymmärrys asiasisällöissä. Kemian opiskelua pidetään haastavana myös oppiaineen luonteen vuoksi: se on abstraktia, teoreettista ja vaikeasti ymmärrettävää. Kemian opiskeluun liittyy muun muassa paljon termejä ja käsitteitä, jotka ovat haastavia oppilaille. (Kousa \& Aksela, 2019) Opettajien suurin huolenaihe on vastata erilaisten oppilaiden tarpeisiin. He kokivat tarvitsevansa enemmän kouluhenkilökunnan tukea ja resursseja sekä taitoja tunnistaa oppilaidensa tuen tarpeita. Opettajat kaipasivat myös oppimista tukevia opetusmetodeja ja -materiaaleja sekä taitoja yhdistää teoreettisiin asioihin käytäntöä oppilaita inspiroivalla ja mielekkäällä tavalla (Kousa \& Aksela, 2019; Kousa, 2019).

Tutkimukset ovat osoittaneet, että opettajaopiskelijat suhtautuvat myönteisesti inklusiiviseen opetukseen (Beacham \& Rouse, 2012; Sharma, Forlin, \& Loreman, 2008; Varcoe \& Boyle, 2014), kuten esimerkiksi oppilaiden oppimisvaikeuksien huomioimiseen osana yleisopetusta (Woodcock \& Vialle, 2016). Toisaalta Varcoen ja Boylen (2014) tutkimus osoitti, että ennen inklusiivista harjoittelua hankittu opetuskokemus on negatiivisesti yhteydessä opettajaksi opiskelevan asenteisiin inkluusiota kohtaan. Tämän vuoksi opettajankoulutuksessa tulee kiinnittää huomiota opiskelijoiden ennakkokäsityksiin jo ennen opetusharjoittelujaksoja.

Jos opettajaopiskelijat eivät tule opiskelujensa aikana tietoiseksi oppijoiden diversiteetistä ja siihen liittyvistä ilmiöistä, tulevat he kohtaamaan haasteita tulevassa työssään (Tolsdorf, Kousa, Markic, \& Aksela, 2018; ks. myös Kousa, 2019). Kousan (2019) tutkimuksessa tulikin esille, että oppilaiden diversiteettiin liittyvien aiheiden opiskelu ja STSE-opetukseen (tiede, teknologia, yhteiskunta ja ympäristö -opetus) perehtyminen sekä käytännön harjoittelu kemian aineenopettajien koulutukseen kuuluvalla opintojaksolla kehitti opettajaopiskelijoiden näkemyksiä diversiteetistä ja erilaisten oppilaiden opettamisesta. Opintojakson jälkeen opettajaopiskelijat kokivat olevansa itsevarmempia opettamaan erilaisia oppijoita. Oman tutkimuksemme kohteena olevan opintojakson kehittäminen lähtee opettajaopiskelijoiden ennakkokäsitysten tarkastelusta. Mielestämme opiskelijoiden ennakkokäsitykset tulee ottaa huomioon ennen kuin tarkastellaan inklusiivista luonnontieteiden opetusta. 


\subsection{Oppilasdiversiteetti luonnontieteiden opetuksessa}

Luonnontieteiden opetuksessa oppilaille voi tuottaa vaikeuksia ymmärtää teoreettisen ja käsitteellisen tiedon suhde käytännölliseen tietoon ja tiedon tuottamisen prosesseihin (Osborne \& Dillon, 2010; Kousa, 2019), mikä kuvastaa luonnontieteellisen tiedon ja toiminnan luonteen ymmärtämisen haasteita. Luonnontieteellisen lukutaidon oppiminen ja opettaminen ovat käytännön tasolla jännitteisiä ja opettajan näkökulmasta vaativia prosesseja (Kokkonen \& Laherto, 2018).

Oppilaille vaikeuksia voivat tuottaa myös luonnontieteissä käytetty kirjallinen, kirjoitettu ja puhuttu kieli (Wellington \& Wellington, 2002; McCarthy, 2005; Evagorou \& Osborne, 2010; Mason \& Hedin, 2011; Kousa, 2019; Sormunen, Lavonen, \& Juuti, 2019). Luonnontieteille ja niiden opetukselle ominaiset matemaattiset ja numeeriset esitysmuodot voivat aiheuttaa ongelmia osalle oppilaista (Brigham, Scruggs, \& Mastropieri, 2011). Akateemiseen suoriutumiseen vaikuttavat myös työmuisti, käyttäytymisen haasteet ja psyykkiset oireet (Aronen, Vuontela, Steenari, Salmi, \& Carlson, 2005).

Kulttuurimme monipuolistuessa on tärkeää havaita tuentarpeet, jotka perustuvat oppijoiden sosiaaliseen, kulttuuriseen ja etniseen taustaan. Lee ja Buxton (2010) käyttävät tällöin oppijoista käsitettä diverse learners. Haasteet voivat liittyä esimerkiksi uuteen opiskelukieleen (Lee \& Fradd, 1998) tai kulttuuritaustoihin perustuvien maailmankuvien eroavuuksiin (Lee \& Buxton, 2010; Piliouras \& Evangelou, 2012). Tuen tarpeet ja heikko koulusuoriutuminen voivat liittyä myös alueellisesti keskittyneeseen väestön heikkoonsosioekonomiseen asemaan (Bernelius, 2011) tai vanhempien vähäisiin mahdollisuuksiin tukea ja kannustaa lapsiaan luonnontieteiden opinnoissa (Smith \& Hausafus, 1998). Lisäksi on havaittu, että sosioekonominen tausta (Gorard \& See, 2009) ja sukupuoli (Greenfield, 1997) ovat yhteydessä oppilaan suhtautumiseen ja asenteisiin luonnontieteiden opiskelua kohtaan. Sukupuoli vaikuttaa esimerkiksi luonnontieteelliseen urasuuntautumiseen (Kupari, Vettenranta \& Nissinen, 2012; Sikora \& Pokropek, 2012).

Myös Suomessa vähävaraisuudella on yhteyttä luonnontieteiden osaamiseen (Kupari ym., 2012; Vettenranta, Hiltunen, Nissinen, Puhakka, \& Rautopuro, 2016). Sosioekonomisen taustan ja sukupuolittuneisuuden vaikutus osaamiseen Suomessa on todettu myös kansainvälisen TIMMS-tutkimuksen tuloksissa vuodelta 2015: verrattuna vuoteen 2011 suomalaisten neljäsluokkalaisten poikien oppimistulokset ovat heikentyneet ja alempi sosioekonominen asema ja 
maahanmuuttajatausta ovat yhteydessä vähäiseen osaamisen tasoon (Vettenranta, Hiltunen ym., 2016). Alueelliset erot maassamme korostuvat ensimmäistä kertaa PISA2015-tutkimuksen tuloksissa: pääkaupunkiseudun oppilaiden menestys luonnontieteissä, lukutaidossa ja matematiikassa oli muuta maata korkeampaa (Vettenranta, Välijärvi ym., 2016).

Luonnontieteiden opetuksessa oppimiseen liittyvät haasteet voivat siis liittyä oppiaineen tai oppijan piirteisiin. Oppilaiden diversiteetin kohtaaminen luonnontieteiden opetuksessa edellyttää opettajalta uudelleen tulkittuja sekä yleisiä että oppiaineen erityispiirteet huomioivia pedagogisia taitoja.

\subsection{Luonnontieteiden oppimisen tukeminen osaksi opettajankoulutusta}

Luonnontieteiden opettajilla on yleensä vähän kokemusta tai taitoja huomioida tukea tarvitsevia oppilaita (Norman, Caseau, \& Stefanich, 1998; Kousa \& Aksela, 2019). Tukea tarvitsevien oppilaiden oppimista luonnontieteissä on tutkittu melko vähän eikä inklusiivisen koulun edellyttämiä muutoksia ole tarkasteltu riittävästi opettajankoulutuksen luonnontieteiden opetuksessa (Asghar, Sladeczek, Mercier, \& Beaudoin, 2017). Luokanopettajaopiskelijoiden kiinnostuksen luonnontieteiden opetukseen on huomattu vähenevän entisestään (Gilbert \& Byers, 2017) ja heidän minäpystyvyytensä luonnontieteiden opetuksen suhteen on havaittu matalaksi (esim. Velthuis, Fisser, \& Pieters, 2014). Toisaalta erityisopettajilla on vähän luonnontieteisiin ja niiden opettamiseen liittyviä tietoja (Villanueva, Taylor, Therrien, \& Hand, 2012). Opettajien eritasoinen osaaminen voi johtua ensinnäkin siitä, että opettajankoulutuksen luonnontieteiden opintojaksoissa ei yleensä tarkastella teoreettiskäsitteellisellä eikä käytännöllisellä tasolla tukea tarvitsevien oppijoiden huomioimista (vrt. esim. Norman ym., 1998). Toisekseen luokan- ja aineenopettajakoulutus järjestetään yleensä erityisopettajakoulutuksesta erillään, jolloin esimerkiksi aineenopettajilla ei ole valmiuksia tuen antamiseen eikä erityisopettajilla riittävää oppiaineen sisältöosaamista (McCarthy, 2005; Villanueva ym., 2012).

Opettajankoulutusten erillisyydellä ja tukimuotojen vähäisellä omaksumisella voidaan ajatella olevan vaikutusta myös opettajien minäpystyvyyden tunteeseen, esimerkiksi suhteessa oppilaiden käyttäytymisen ohjaamistaitoihin (Malinen \& Savolainen, 2016). Kuitenkin juuri tarve ohjata oppilaiden käyttäytymistä aiheuttaa hämmennystä työuran alkuvaiheessa ja ensimmäiset työyhteisöt ovat opettajalle merkittäviä eriyttävän opetuksen harjoitteluympäristöjä (esim. Mulholland \& 
Wallace, 2001). Opettajien minäpystyvyyttä inklusiivisessa opetuksessa on kehitetty keskittymällä esimerkiksi oppimis- ja opetusstrategioihin sekä luokanhallintataitoihin (Chao, Sze, Chow, Forlin, \& Ho, 2017).

Näkemys oppijoiden tukemisesta eri oppiaineiden opetuksen ja oppimisen kontekstissa on jäänyt pinnalliseksi; oppijan ilmeisimmät ominaisuudet ja taustatekijät, kuten äidinkieli, sukupuoli tai oppimisvaikeus todetaan, mutta opettajaopiskelijat ohittavat tunnistamattomat kulttuuriset mallit ja ennakkoasenteet, jotka säätelevät suhtautumista itselle uudenlaisiin ihmisiin (Moore, 2008). Tällaisten käsitysten pohdinta osana opettajankoulutusta voi nostaa esiin luonnontieteiden opetustilanteisiin sisältyviä ja vuorovaikutukseen vaikuttavia oletuksia, jotka olisi syytä reflektoida tarkemmin. Perinteiseen ja segregoivaan opetukseen liittyvät uskomukset olisi tärkeää työstää, jotta tietoisuus oppilasdiversiteettiä hyödyntävästä inklusiivisesta opettajuudesta (Kugelmass, 2001) voisi saada eksplisiittisiä muotoja. Oppilasdiversiteetin kasvaessa tulee opettajankoulutuksessa löytää tapoja, joilla voidaan vahvistaa opettajaksi opiskelevien taitoja toimia inklusiivisessa koulussa.

\section{Tutkimuksen toteuttaminen}

Opettajankoulutuksessa voidaan inklusiivista opetusta ja oppimisen tukea tarkastella erilaisin opintojaksototeutuksin: a) erityispedagogisella opintojaksolla (vrt. esim. Sharma \& Sokal, 2015), b) käyttämällä läpäisyperiaatetta (vrt. esim. Lambe, 2011), jolloin teema on kirjattu opettajankoulutuksen opetussuunnitelmaan, mutta vastuu inklusiivisen opetuksen huomioimisesta on yksittäisen opintojakson kouluttajalla, tai c) siten, että opettajankouluttajat tuovat sitoutuneesti yhteistyössä kyseistä teemaa esiin "diffuusisti" eri opintojaksoilla useamman opiskeluvuoden aikana (vrt. Sharma ym., 2008). Itä-Suomen yliopiston perusopetuksessa opetettavien aineiden ja aihekokonaisuuksien monialaisissa opinnoissa sovelletaan edellä mainittua diffuusiomallia, jolloin eri oppiaineiden opintojaksoilla erityispedagoginen näkökulma tuodaan esiin oppiainepedagogiikan ja erityispedagogiikan asiantuntijoiden välisenä yhteistyönä eri oppiaineiden opintojaksoilla.

Tutkimuksemme on osa praktista toimintatutkimusta, jonka tarkoituksena on kehittää "Tutkiva oppiminen luonnontieteiden opetuksessa ja oppimisessa, A-osa, 3,5 op” -opintojaksoa. Siihen kuuluu luonnontieteiden sisällön ja pedagogiikan ohella myös oppimisen tuen näkökulma (Itä-Suomen yliopisto, 2016): ”...Opintojaksolla 
tarkastellaan oppijan ennakkotietämystä ja asenteita luonnontieteiden oppimisen lähtökohtana sekä mahdollisia erityisen tuen tarpeita...”Opintojakso kuuluu keväällä ensimmäisen lukuvuoden opintoihin, eikä opiskelijoilla ole ollut opettajankoulutuksessa muita luonnontieteiden tai erityispedagogiikan opintojaksoja ennen sitä. Ennen opintojakson alkua opintojaksolle ilmoittautuneille opiskelijoille annetaan heidän ennakkotietämystään aktivoiva, sähköisessä muodossa oleva opintotehtävä, jossa heitä pyydetään ottamaan kantaa kysymykseen: "Missä tapauksissa luonnontieteiden opiskelussa ja oppimisessa erilaiset oppijat mielestäsi tarvitsevat tukea? Perustele ja anna esimerkkejä.” Seuraava esimerkki on lainaus eräästä vastauksesta:

\begin{abstract}
"Tukea voi tarvita missä vain, riippuen oppilaasta. Esim. pyörätuolissa istuvan oppilaan saaminen metsään voi olla hankalaa, lukihäiriöisen on hankala lukea myös luonnontieteiden oppikirjaa ja tehdä tehtäviä kirjallisesti. Jos esim. fykessä tehdään kokeita, pitää turvallisuuteen kiinnittää erityistä huomiota, jos luokassa on ylivilkkaita/käytöshäiriöisiä lapsia, ettei oppimistilanne muutu vaaralliseksi. Oppilaiden huomio pitäisi saada pysymään aiheessa, koska erilaisissa kokeiluissa huomio voi kiinnittyä helposti epäolennaisuuksiin.” (22.15)
\end{abstract}

Olemme koonneet vuosina 2015-2018 opintojaksolle osallistuneiden 491 opiskelijan opintotehtävän vastauksista aineiston, jonka tutkimuskäyttöön on vapaaehtoisesti antanut luvan (Tutkimuseettinen neuvottelukunta, 2019) 468 luokanopettaja- ja erityisluokanopettajaopiskelijaa. Tutkimukseen osallistuneiden opiskelijoiden vastaukset koodattiin juoksevin numeroin ja aineistonhankintavuoden mukaan; koodit ovat esillä myös jäljempänä analyysin kuvaukseen ja tulosten esittämiseen liittyvissä esimerkkilainauksissa. Aineistossa opiskelijoiden vastaukset vaihtelivat suppeasta yhden lauseen luettelomaisesta vastauksesta laajaan 18 lauseen vastaukseen. Suuri aineistokoko muodosti kuitenkin kokonaisuutena rikkaan aineiston, koska se sisälsi monipuolisesti erilaisia ennakkokäsityksiä. Aineistoa hyödynnetiin ja hyödynnetään opintojakson sisältöjen kehittämisessä.

Tehtävänannossa olevaa ilmaisua "erilaiset oppijat" on käytetty kuvaamaan oppilaiden diversiteettiä. Inklusiivisen opetuksen yhteydessä tällä ilmaisulla voidaan viitata esimerkiksi tiettyyn ryhmään, joilla ajatellaan olevan erityisiä tarpeita opiskelussaan (students with special educational needs, ks. Villanueva ym., 2012). Tällöin aihepiirin tutkimuksissa käsitellään esimerkiksi oppimisvaikeuksia (Krull, Wilbert, \& Hennemann, 2014), vammaisuutta (Round, Subban, \& Sharma, 2016) tai muutoin diagnosoitavissa olevia neurobiologisia kehityshäiriöitä (Young 
ym., 2017). Toinen näkökulma, jonka olemme edellä luonnehditun "erityisoppilaat"näkemyksen lisäksi halunneet sisällyttää "erilaiset oppijat" -ilmaisun alle, on aiemmin mainitsemamme kulttuurinen erilaisuus. Tällöin tuen tarpeiden tarkastelu liittyy oppijoiden sosiaaliseen, kulttuuriseen ja etniseen taustaan (ks. Lee \& Buxton, 2010: diverse learners) sekä sukupuoleen, seksuaaliseen orientaatioon, lahjakkuuteen, oppijan kokemuksiin, näkemyksiin, asenteisiin ja persoonallisuuteen (ks. esim. Goethe \& Colina, 2018; Wassel ym., 2018; Kousa \& Aksela, 2019).

Tunnistamme kysymyksen asettelun luovan inkluusiota kategorisoivasti luonnehtivaa todellisuutta, mutta olemme pyrkineet käyttämään opiskelijoille ilmiötä arjessa avaavaa ja ymmärrettävää kieltä. Sana "erilaiset” johdattavat vastaajaa myös ottamaan kantaa siihen, millaisia oppijoita he vastauksissaan tarkoittavat.

Aineiston analyysi perustui laadulliseen induktiiviseen sisällönanalyysiin (Hsieh \& Shannon, 2005; Schreier, 2014). Kaksi tutkijaa luki tekstiaineistot huolellisesti läpi siten, että toinen heistä keskittyi vuosien 2015 ja 2016 aineistoihin ja toinen 2017 ja 2018 aineistoihin. Tämän jälkeen ensiksi mainittu tutkija luokitteli aineiston kahteen pääteemaan: tuki, joka kohdistuu yksilöön (Taulukko 1) - "Jos on oppilas, jolla lukivaikeus, keskittymisvaikeus tai dysfasia, täytyy tämä huomioida opetuksen järjestyksessä...” (14.16) - ja tukeen, joka perustuu ympäristöopin ominaispiirteisiin (Taulukko 2) - ”... Joskus luonnontieteessä tulee vastaan sellaisia sanoja ja käsitteitä, joita voi olla vaikea ymmärtää tai ne voi ymmärtää väärin, esim. kitka ja kasvukausi...” (165.15). Tämän jälkeen tutkija muodosti kummastakin teemasta alustavat alakategoriat (ks. esim. Taulukko 1: "Kielelliset vaikeudet"), alakategorioita yhdisteltiin yläkategorioiksi (Taulukko 1: "Oppimisvaikeuksien kautta nimetyt tuentarpeet”) ja yläkategorioita pääkategorioiksi (Taulukko 1: “Oppilaan oppimis- ja toimintakykyyn liittyvät tuentarpeet”). Toinen tutkija sovelsi edellä mainittua luokittelua vuosien 2017 ja 2018 aineistoihin, minkä jälkeen analyysiä tarkennettiin ala- ja yläkategorioiden nimeämisen suhteen käyttäen tutkijatriangulaatiota (vrt. Schreier, 2014).

Tiedostamme, että jo aineiston luokittelu sinänsä sekä kategorioiden nimeäminen tuottavat osaltaan todellisuutta, joka on inkluusiokäsitteen näkökulmasta vierasta. Tätä ei voida kuitenkaan aineiston analyysissä välttää, kun tavoitteena on tunnistaa ja tarkastella erilaisia opiskelijoiden käsityksiä tuen tarvitsijoista ja tuen tarpeista luonnontieteiden opetuksessa. 


\section{Tulokset}

Tuen tarpeen käsittely jakautui karkeasti ottaen seuraavasti. Ensinnäkin havaittiin, että tuentarvetta perusteltiin oppilaskohtaisten ja yksilöihin liitettyjen ominaisuuksien kautta. Tämä viittaa käsitystapaan, jossa oppimisen tuentarve liitetään lähtökohtaisesti oppilaaseen henkilönä ja tuki mielletään usein myös ratkaisuna ongelmaan tai heikkouteen. Toisaalta havaittiin, että opiskelijat liittivät oppilaiden tuentarpeet myös oppiaineen eli ympäristöopin ominaispiirteisiin, kuten sisältöihin ja opetustilanteisiin.

\subsection{Oppilaskohtaiset tuen tarpeet}

Kun tuentarve perustui oppilaan ominaisuuksiin, jakautuivat opiskelijoiden käsitykset kolmeen pääluokkaan. Tuentarvetta kuvailtiin oppilaan oppimis- ja toimintakykyyn, opiskelumotivaation ja -orientaation vaihteluun sekä kulttuurisiin eroihin ja oppilaan taustatekijöihin liittyvien näkökohtien avulla (Taulukko 1).

Oppimis- ja toimintakykyyn sisältyi nimettyjä ja esimerkiksi neurologisesti ja psykologisin testein tutkittavissa ja diagnosoitavissa olevia oppimisvaikeuksia. Oppimisvaikeuksista opettajaopiskelijat mainitsivat yleisimmin lukemisen vaikeudet, keskittymis- ja tarkkaavaisuusvaikeudet, hahmottamisongelmat sekä matematiikan oppimisvaikeudet - "... lukivaikeudesta kärsivällä lukijalla voi olla vaikeaa lukea teoriaa kirjasta ja sisäistää asiaa samaan tahtïn kun muiden. Hän saattaa tarvita saman tekstin lukemiseen paljon enemmän aikaa. " (103.16). Osin asian käsitteellistäminen pitäytyi ylätasolla, jolloin kuvauksena olivat kognitiiviset vaikeudet ja yleensä oppimisen ongelmat. Käsitteellistämisen täsmentyessä käytössä olivat myös neurologiset ja lääketieteelliset termit, kuten dysfasia, ADHD, dysleksia ja autismi - "...Esim. ADHD lapsi tarvitsee selkeitä toimintaohjeita ja tarpeeksi virikkeitä esim. metsässä selkeät ohjeet etukäteen, että keskittyminen ei herpaannu..."(27.17).

Opiskelijoiden mukaan tuentarve luonnontieteiden opetuksessa voi perustua myös pedagogisiin havaintoihin, kuten opettajan havaitsemaan lasten kehitysnopeuden vaihteluun, toiminnan hitauteen, oma-aloitteisuuden vähäisyyteen tai erityiseen lahjakkuuteen - "Jotkut asiat voivat olla toisille hankalia ja toisille todella nopeita ja helppoja. Tämä tuo ongelman silloin kun tehdään esimerkiksi havainnollistavia kokeita luokassa. Osa ryhmästä saattaa saada tehtävän todella nopeasti valmiiksi, kun osa oppilaista ei saata olla vielä edes kerennyt hakea 
välineitä tarvittavan testin suorittamiseen." (126.16). Lisäksi opiskelijat mainitsivat fyysisten rajoitteiden ja terveyden kautta nimettyjä tuentarpeita, kuten fyysiseen toimintakykyyn, aistitoimintoihin ja terveydentilaan liittyviä rajoitteita - "...liikunta rajoitteinen taas tarvitsee erityistä huomiota esimerkiksi metsäretkien aikana." (144.15).

Taulukko 1. Opiskelijoiden käsitykset oppilaiden ominaisuuksiin perustuista tuen tarpeista

Tuen tarpeet

1. Oppilaan oppimis- ja toimintakykyyn liittyvät tuentarpeet (268)

\section{Käsitys oppilaiden tuentarpeen syystä}

1.1 Oppimisvaikeuksien kautta nimetyt tuentarpeet (218)

- kielelliset vaikeudet: eri asteiset lukemisen vaikeudet (59), dysleksia (2), dysfasia (3), kommunikointiongelmat (1)

- matematiikan oppimisvaikeudet (29)

- eriasteiset neurobiologiset ja neuropsykiatriset vaikeudet ja häiriöt: ADHD (3), autismi (1)

- perustason kognitiiviset toiminnot: muistiongelmat (6), keskittymisja tarkkaavaisuusvaikeudet (43), hahmottaminen (32), toiminnanohjauksen haasteet (7), hienomotoriikan poikkeavuudet (4)

- sosio-emotionaaliset vaikeudet (3)

- yleismaininnat "oppimisvaikeuksista" tai "kognitiivisista vaikeuksista" (25)

1.2 Pedagogisten havaintojen kautta nimetyt tuentarpeet (25) lasten kehitysnopeuden vaihtelu (2), toiminnan hitaus (11), omaaloitteisuuden puute (2), lahjakkuus ja nopeus suoriutua tehtävistä (10) 1.3 Fyysisten rajoitteiden ja terveydentilan kautta nimetyt tuentarpeet (25)

fyysisen liikkumisen haasteet (13), allergiat (1), aistitoiminnot (11)

2. Opiskelumotivaation ja orientaation vaihteluun liittyvät tuentarpeet (106)
2.1 Erilaiset kiinnostuksen kohteet ja motivaatio (44)

2.2 Ennakkotiedot ja -taidot (32)

2.3 Erilaiset oppimistyylit (29)

2.4 Minäpystyvyys (1)
3. Kulttuurisiin eroihin ja oppilaan taustaan liittyvät tuentarpeet (12)
3.1 Opiskelukieli (suomen kieli) (7)

3.2 Katsomukselliset erot (3)

3.3 Sukupuoli (1)

3.4 Sosioekonominen tausta (1)

Oppilaan oppimis- ja toimintakyky -pääluokka sisältää kuvauksia vaikeuksista, viivästymisestä ja ongelmista. Vain lahjakkuus rikkoi oppilaan ominaisuuksiin liitetyssä luokittelussa ongelmakeskeistä näkökulmaa - "... Lahjakkaat ja tiedonjanoiset oppilaat tarvitsevat HAASTETTA ja MAHDOLLISUUDEN KOKEILLA OPPIMISEN RAJOJA.” (5.17). 
Selkeästi erityyppisen tulkintakehyksen muodosti opiskelumotivaatioon ja orientaatioon liitetty kuvailu. Opiskelijat kiinnittivät huomiota erilaisiin kiinnostuksen kohteisiin ja motivaatioihin, eritasoisiin ennakkotietoihin ja -taitoihin - "Uuden oppiminen vaatii monesti aiemmin opetettavien asioiden sisäistämistä. Jokainen lapsista ei ole välttämättä oppinut aiemmin opetettuja asioita. Luokan oppilaiden "Lähtötason" selvittäminen onkin mielestäni tärkeää ja opetuksen tulee lähteä tästä liikkeelle. Myös esimerkiksi kïnnostus aineeseen ja motivaatio oppimiseen voi olla monella kadoksissa. Kïnnostuminen ja motivaatio on kuitenkin oppimisen taustalla, joten innostava ja havainnollinen opetustyyli on tärkeää.” (43.15). Myös oppilaiden oppimistyylien huomioimista pidettiin tärkeänä luonnontieteiden opetuksessa - "...Toiset oppivat mm. kuuntelemalla ja toiset lukemalla, kolmas puolestaan käytännön esimerkeilläja tutkimuksilla. Tällöin pitää mahdollisesti tarjota kaikkia mahdollisia oppimismetodeja, josta löytyy mahdollisesti jokin sopiva tapa/ sopivien tapojen yhdistelmä kaikille.” (156.15).

Vähiten tuentarvetta liitettiin kulttuurisiin ja oppilaan kasvun taustoihin liittyviin näkökulmiin. Vain seitsemän opiskelijan mielestä opetustilanteissa tulisi huomioida suomen kielen osaamiseen liittyviä ymmärtämisen ongelmia - ”... maahanmuuttajaoppilailla voi olla vaikeuksia luonnontieteiden opetuksessa käytettävän sanaston kanssa, sillä monet sanat voivat olla heille täysin uusia..." (99.16). Lisäksi opiskelijat huomioisivat arvoihin, elämänkatsomukseen ja uskonnolliseen taustaan liittyvät seikat - "Aatteellisesti erilainen oppija,jonka kotona ei esimerkiksi uskottaisi tieteisiin tai evoluutionteoriaan, tarvitsee varmasti paljon tukea asioiden monipuoliseen ymmärtämiseen ja vaihtoehtojen tarkasteluun..." (50.18). Yksittäisten opiskelijoiden mielestä opettajan tulisi huomioida opetustilanteissa sukupuolisuus tai oppilaan sosioekonominen tausta ja kodin mahdollisuudet tukea lapsen koulunkäyntiä - "...Kotiolot ja asuinympäristö rajoittavat esimerkiksi kasvien keräämistä kotitehtävänä.”(100.17).

\subsection{Ympäristöopin ominaispiirteisiin liittyvåt tuen tarpeet}

Opiskelijat tarkastelivat oppilaiden tuen tarpeita myös oppiaineen eli ympäristöopin ominaispiirteiden näkökulmasta. Opettajaopiskelijoiden mielestä oppilaat tarvitsevat tukea luonnontieteiden oppisisältöjen oppimiseen. Heidän mukaansa tukea tarvitaan yleensä käsitteellisiä ja teoreettisia sekä vaikeita käsitteitä ja asioita opiskeltaessa (Taulukko 2). 
Taulukko 2. Opiskelijoiden käsitykset ympäristöopin ja sen opetuksen ominaispiirteisiin liittyvistä tuen tarpeista

\begin{tabular}{|c|c|}
\hline Tuen tarpeet & Käsitys tuen tarpeesta ympäristöopin opetuksessa \\
\hline $\begin{array}{l}1 \text { Oppiaineiden sisältöihin } \\
\text { liittyvät tuentarpeet (136) }\end{array}$ & 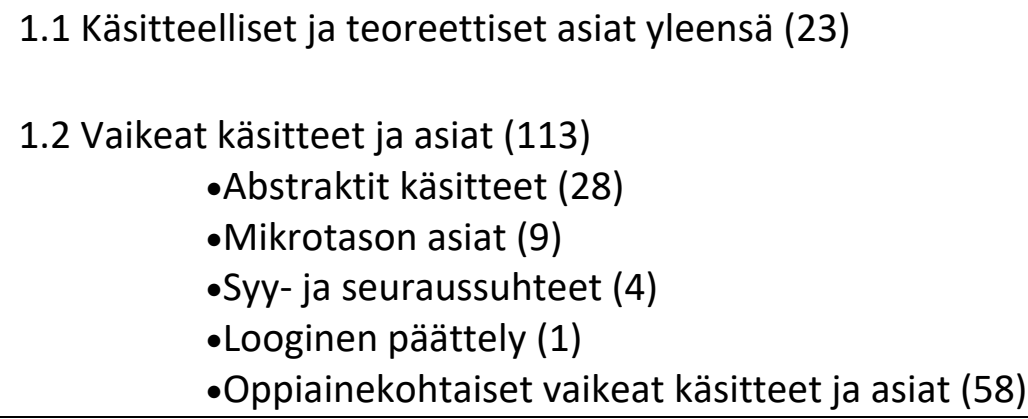 \\
\hline $\begin{array}{l}2 \text { Opetustapahtumaan } \\
\text { liittyvät tuen tarpeet (263) }\end{array}$ & $\begin{array}{l}\text { 2.1 Opiskeluprosessi (193) } \\
\text { •Käsitteiden oppiminen ja ymmärtäminen (57) } \\
\text { •Luetun ymmärtäminen (34) } \\
\text { •Käsitteiden muistaminen ja ulkoa opettelu (30) } \\
\text { •Laajojen kokonaisuuksien hahmottaminen (28) } \\
\text { •Symboliikka ja kaavat (17) } \\
\text { •Laskutehtävät (10) } \\
\text { •Tietojen soveltaminen (6) } \\
\text { •Kirjalliset tehtävät (5) } \\
\text { •Luonnontieteellisen kielen ymmärtäminen (2) } \\
\text { •Itsenäinen työskentely (2) } \\
\text { •Ongelmanratkaisu (1) } \\
\text { •Tehtävien alkuun- ja loppuun saattaminen (1) } \\
\text { • Käytännön harjoitukset, oppilaiden } \\
\text { tutkimustyöskentely ja projektityöskentely (39) } \\
\text { •Yhteisöllinen oppiminen (16) } \\
\text { •Opettajajohtoinen opetus (6) } \\
\text { •Oppetusmenetelmästä toiseen siirtyminen (3) }\end{array}$ \\
\hline & $\begin{array}{l}\text { 2.3 Erilaiset oppimisympäristöt (6) } \\
\text { •Luonnon ympäristöt (5) } \\
\text { •Uudet ympäristöt (1) }\end{array}$ \\
\hline
\end{tabular}

Opiskelijoiden mielestä luonnontieteissä on erityisen paljon abstrakteja käsitteitä ja mikrotason asioita, joita ei voi konkreettisesti nähdä - ”... Luonnontieteissä on paljon abstrakteja "ei-käsinkosketeltavia" käsitteitä, kuten sähkö, painovoima ja mikrobiologia." (86.16). Lisäksi luonnontieteiden opiskeluun liittyvien kognitiivisten prosessien, kuten syy- ja seuraussuhteiden ymmärtämisen ja loogisen päättelyn arveltiin tuottavan ongelmia oppilaille - "Tukea tarvitaan erilaisten käsitteiden ja ilmiöiden yhdistämisessä, syy-seuraus suhteiden jäsentämisessä mm. mannerlaattojen liike joka johtaa maanjäristykseen ja tätä kautta mahdollisesti tsunamiin tai tulivuorenpurkaukseen...”(115.17).- Opiskelijoiden mainitsemia 
vaikeina pidettyjä biologian ja maantieteen asioita olivat muun muassa lajintuntemus, kartanluku, yhteyttäminen ja ravintoketjut. Vastaavasti vaikeita fysiikan ja kemian aihealueita olivat esimerkiksi voima, reaktiot, valo, planetaarisuus, avaruus, molekyylit, ilma, kitka ja sähkö.

Opettajaopiskelijoiden mukaan oppilaiden tuentarpeet liittyvät myös opiskeluprosessiin sekä luonnontieteiden opetukselle ominaisten opetusmenetelmien että oppimisympäristöjen käyttöön. Haasteellisiksi opiskeluprosessin osiksi nimettiin käsitteiden, luonnontieteellisen kielen sekä luetun tekstin oppiminen ja ymmärtäminen - "Luonnontieteissä on paljon käsitteitä ja ilmiöitä, joiden ymmärtäminen on oppimisen perusta. Näissä asioissa jotkin oppilaat voivat tarvita tukea." (5.16). Vaikeina asioina pidettiin myös käsitteiden muistamista ja ulkoa opettelua sekä laajojen kokonaisuuksien hahmottamista "Luonnontieteiden opiskelussa on tyypillisesti hankalia ja pitkiä oppikirjan tekstejä, jotka voivat tuottaa hankaluuksia. Nimien opettelu ulkoa voi myös olla vaikeaa." (39.15) - Lisäksi luonnontieteiden opiskelulle ominaisten symbolien ja kaavojen, laskutehtävien sekä tiedon soveltamisen arveltiin tuottavan oppilaille ongelmia "Tukea tarvitaan erityisesti erilaisten kaavojen omaksumisessa ja nïden hyödyntämisessä käytäntöön. Ei siis opeteltaisi kaavoja vaan siksi, että ne täytyy osata, vaan pyrittäisïn syvällisempään ymmärtämiseen ja opittaisiin, mikä nïden idea ja tarkoitus on...” (99.15). Yksittäisten opiskelijoiden mukaan haastavia opiskeluprosessiin kuuluvia asioita ovat muun muassa kirjalliset ja ongelmanratkaisuun pohjautuvat tehtävät sekä itsenäisen työskentelyn - ”...Kokeet voitaisiin tehdä muuten kuin kirjallisina jos se tuottaa ongelmia, ettei omien taitojen osoitus jäisi süitä kïnni.”(53.16).

Luonnontieteiden opetukselle ominaisten opetusmenetelmien käyttö voi lisätä tuen tarvetta. Tällaisia opiskelijoiden mainitsemia opetusmenetelmiä olivat käytännön harjoitukset (kokeelliset tehtävät, maasto-opetus, oppilaiden tutkimustyöskentely) ja projektityöskentely - "Erilaiset oppijat tarvitsevat apua esimerkiksi kokeiden tekemisessä. Se, että jokainen pääsee perille käsiteltävästä aiheesta ja tajuaa tehtävänannon, on tärkeää. Esimerkiksi tutkittaessa jotakin kemiallista reaktiota jokainen oppilas tulisi perehdyttää välineisïn ja saada tehtävän alkuun. Esimerkiksi henkilöllä,jolla on keskittymisen kanssa ongelmia, voi olla vaikea kuunnella ohjeita ja siksi tehtävänano voi mennä aluksi ohi.” (84.16). Edellä mainittujen opetusmenetelmien käytössä tukea arveltiin tarvittavan erilaisten aineiden ja tutkimusvälineiden käsittelyssä, havaintojen tekemisessä, 
työskentelyturvallisuudessa, ohjeiden noudattamisessa sekä keskittymisessä - ”... Jos esim. fykessä tehdään kokeita, pitää turvallisuuteen kiinnittää erityistä huomiota, jos luokassa on ylivilkkaita/käytöshäiriöisiä lapsia, ettei oppimistilanne muutu vaaralliseksi. Oppilaiden huomio pitäisi saada pysymään aiheessa, koska erilaisissa kokeiluissa huomio voi kiinnittyä helposti epäolennaisuuksiin.”(30.15).

Myös tiedon hankinta, tutkimusongelmien asettaminen, tutkimusmenetelmien valinta, mittaaminen, tulosten tulkinta, itsenäinen työskentely ja monista työvaiheista suoriutuminen nähtiin oppilaille haasteellisina prosesseina - "Tukea tarvitaan mietittäessä mikä on ongelma, millä eri keinoin sitä voisi ratkaista ja mihin lopputuloksïn päädytään. Mitä voimme päätellä loppuratkaisusta? Avustavat kysymykset ja johdattelu.” (151.15). - Edellisten lisäksi yhteisöllisen oppisen käytön - "... Luonnontieteiden opetuksessa oppilas voi tarvita tukea sosiaalisissa taidoissa. Opetuksessa tehdään paljon ryhmätöitä ja tutkitaan yhdessä..." (34.17) - ja opettajajohtoisen opetuksen - "Luentomuotoinen opetus (opettaja opettaa taululla edessä ja oppilaat kirjoittavat) voi olla monille oppilaille haastavaa. Tällaisessa tilanteessa esim. Oppimisvaikeuksiset lapset tarvitsevat tukea, apua ja vaihtoehtoisia opiskelumuotoja...” (85.15) - arveltiin lisäävän oppilaiden tuen tarvetta.

Opiskelijoiden mukaan myös erilaisissa ja uudenlaisissa oppimisympäristöissä opiskelu vaatii oppilaiden opiskelun tukemista. Eniten opiskelijoiden vastauksissa mainittiin koulun ulkopuolisia oppimisympäristöjä, kuten luonto ja metsät - "... Jos ei ole helppoa löytää havaintoja ympäristöstä, tai esimerkiksi muuttuva oppimisympäristö vain häiritsee oppimista (esim. metsässä liikkuminen ja tutkiminen mikä ei sisällä rutiineja).”(4.15)

\section{Pohdinta}

Opiskelijoiden vastauksista ilmeni, että enemmistö opiskelijoista tarkasteli oppilaiden diversiteettiä ongelmakeskeisestä näkökulmasta, jolloin luonnontieteiden opetuksen tuen tarpeet nähtiin liittyvän johonkin diagnosoituun oppimisvaikeuteen. Monet oppimisen esteet eivät kuitenkaan ole ensisijaisesti oppilaan persoonaan sidottuja eikä edes diagnosointi aina johda suoriin pedagogisiin johtopäätöksiin. Luonnontieteiden opetuksen näkökulmasta onkin tärkeää, että opettaja tunnistaa mahdollisemman laajasti oppimisen esteet ja pystyy pedagogisesti lapsen omassa toimintaympäristössä tukemaan kaikkien oppilaidensa oppimista (vrt. Aronen ym., 2005; Opetushallitus 2014; Villanueva ym., 2012). Opiskelijoiden käsityksistä ei vielä 
tässä vaiheessa opintoja löytynyt laajemmin kuvauksia tuentarpeen moniulotteisuudesta. Esimerkiksi lahjakkaan lapsen mahdollinen tuentarve näkyi aineistossa vain hyvin kapeasti (vrt. Foley-Nipcon ym., 2013.) Opettajakoulutuksessa olisikin syytä varoa yksipuolista ongelmakeskeistä oppilasdiversiteettitarkastelua, ja koulutuksen lähtökohtana tulisi olla laajan diversiteetin tunnistaminen ja kaikenlaisten oppilaiden oppimisen tukeminen (Ainscow ym., 2006; Kiuppis \& Hausstätter, 2014, Kousa \& Aksela, 2019; Slee, 2001).

Opiskelijoilla oli myös varsin kattava käsitys siitä, että oppilasryhmässä voi olla eritavoin orientoituneista oppilaita. Opiskelijoiden mukaan luonnontieteiden opetuksessa tulisi huomioida esimerkiksi oppilaiden motivaation tukeminen ja ennakkotietämys. Luonnontieteiden opetuksen tuleekin tarjota oppilaille mahdollisuuksia tuoda esiin omaa osaamistaan ja arkielämän kokemuksia sekä tarjota myönteisiä kokemuksia kaikille oppilaille (Villanueva ym., 2012). Opiskelijoiden melko laajasti mainitsemat oppimistyylit olivat jossain määrin hämmentävä havainto. Oppimistyyli voi toki olla arkikieltä ja siten sisältää kuvausta oppimisen monenlaisuudesta, mutta sillä voidaan myös viitata oppimistutkimuksessa kritisoituun käsitteistöön, jonka toimivuus on vähintäänkin ristiriitaiseksi osoitettu (Pashler, McDaniel, Doug Rohrer, \& Bjork, 2009; An \& Carr, 2017).

Opiskelijoiden vastauksissa oli vain yksittäisiä mainintoja sukupuolesta ja sosioekonomisesta asemasta. Koska näillä on havaittu olevan merkitystä luonnontieteiden opintomenestykseen, opiskeluasenteisiin ja urasuuntautumiseen sekä ulkomailla (Gorard \& See, 2009, Greenfield, 1997) että Suomessa (Bernelius, 2011; Kupari ym., 2012; Vettenranta, Hiltunen ym., 2016) tulisi mainittuja näkökulmia käsitellä myös opettajankoulutuksessa. Opettajaopiskelijat eivät myöskään osanneet nimetä kattavasti kulttuurisia ja arvopohjaisia tuentarpeita. Heidän oma koulukokemuksensa on voinut olla hyvin kansalliseen valtakulttuuriin perustuva ja toisaalta monikulttuurisuutta käsittelevät opintojaksot eivät vielä olleet heidän opinnoissaan alkaneet. Kulttuuritaustoihin perustuvien maailmankuvien eroavuuksiin tunnistaminen on kuitenkin tärkeä huomioida monikulttuurisessa kouluyhteisössä (vrt. Lee \& Buxton, 2010; Opetushallitus, 2014; Piliouras \& Evangelou, 2012).

Opettajaopiskelijat tarkastelivat oppilaiden tuen tarvetta myös oppiaineiden sisältöihin ja opetustapahtumaan liittyen. Opiskelijat mainitsivat useita erilaisia opiskeluprosesseja (käsitteiden oppiminen ja muistaminen, luetun ymmärtäminen, symboliikka jne.) ja opetusmenetelmien käyttötilanteita (kokeellisuus, maasto- 
opetus, oppilaiden tutkimustyöskentely jne.), joissa oppilaat voivat tarvita tukea. Opiskelijoiden havaitsemat tuentarpeita paljastavat tilanteet ovat juuri niitä, joissa heidän tulisi oppia tarjoamaan tukea lapsille. Opiskelijoiden käsitykset olivat kuitenkin osin ristiriidassa aiempien tutkimustulosten kanssa. Opiskelijat esimerkiksi nimesivät tuentarvetta tuottaviksi samoja opetusmenetelmiä, joita tutkimus (ks. esim. Mastropieri ym., 1998; Therrien, Taylor, Hosp, Kaldenberg \& Gorsh, 2011) esittää ratkaisuksi oppilaiden tukemiseen. Opetussuunnitelman ja tutkimusten mukaan luonnontieteiden oppimista tukee opiskelu- ja opetusmenetelmien sekä oppimisympäristöjen monipuolinen käyttö (vrt. Ainscow, Booth, \& Dyson, 2004; Kousa, 2019; Opetushallitus, 2014; Sormunen ym., 2019; Varelas, Kane, \& Wylie, 2011; Villanueva ym., 2012). Opettajaopiskelijat eivät vastauksissaan käyttäneet käsitettä "tutkiva oppiminen"; tätä selittänee se, ettei heillä vielä opintojensa alkuvaiheessa ollut ymmärrystä kyseisestä käsitteestä. Toisaalta syynä voi olla se, että he pysyttäytyivät vastauksissaan melko traditionaalisissa ja oman osaamisen kannalta "turvallisissa aktiviteeteissa” (ks. Appelton \& Kindt, 2002). Opettajakoulutuksessa tulisikin tarkastella luonnontieteiden opettamista positiivisesti ainepedagogisesta näkökulmasta kysymällä, millaisia mahdollisuuksia oppiaineelle tyypilliset opiskeluprosessit, opetusmenetelmät ja oppimisympäristöt voivat tarjota erilaisille oppijoille (vrt. Varelas ym., 2011). Lisäksi koulutuksen tulisi sisältää tutkimuksellista tietoa siitä, millaisten asioiden ja taitojen oppiminen ovat haastavia luonnontieteiden opetuksessa: esimerkiksi luonnontieteellisen tiedon luonne (Osborne \& Dillon, 2010), kieli (Evagorou \& Osborne, 2010; Mason \& Hedin, 2011) ja matemaattinen esitystapa (vrt. Brigham ym., 2011).

Opiskelijat käyttivät runsaasti terminologiaa ja käsitteitä erilaisten oppimisvaikeuksien nimeämisessä. Osin terminologia oli toisaalta hyvinkin epätarkkaa, mutta käytössä oli myös määriteltyjä diagnoosinimikkeitä. Tästä ei kuitenkaan voida tehdä suoraan johtopäätöksiä siitä, tuntevatko he käyttämiensä käsitteiden tai diagnoosinimikkeiden eksakteja sisältöjä ja määritelmiä. Myös opiskelijoiden pedagogisten ilmaisujen ja käsitteiden käyttö vaihteli. Kaiken kaikkiaan tutkimuksemme osoitti, että opiskelijoiden käsityksien kirjo oli laaja. Tulosten perusteella opiskelijoiden käsitys oppilasdiversiteetistä on melko laaja pitäen sisällään perusopetuksen oppilaat monipuolisesti ymmärrettyinä yksilöinä. Luonnontieteiden ainedidaktiikan tulee sisältää myös oppiaineen kannalta keskeisten opiskelutaitojen ohjausta, kun tarkastellaan oppilaiden oppimista luonnontieteiden tunneilla. 
Tutkijoina asetimme itsellemme tutkimustehtävän, jonka mielekkyyttä pitää myös arvioida eettisesti. Jos tavoitteenamme opettajankoulutuksen tutkijoina on kehittää opettajuutta ja tutkimusta kohti inklusiivisen koulun käytänteitä, niin miksi ylipäätään tarvitaan tuen tarpeen luokittelua tai edes abstrakteja kuvitteellisiin oppilaisiin liitettäviä luokittelunimikkeitä (vrt. Ahtiainen, Lintuvuori, Hienonen, Jahnukainen, \& Hautamäki, 2017)? Pidämme kuitenkin tärkeänä opiskelijoiden pedagogisten käsitysten kartoittamista. Näiden käsitysten tunnistaminen ja nimeäminen on opettajankoulutuksen näkökulmasta tarpeellista, jotta opiskelijoiden havainnoista päästään keskustelemaan. Opiskelijoiden tulisi ymmärtää opetuksen lähtökohdaksi myönteinen suhtautuminen oppilasdiversiteettiin (Ainscow ym., 2006; Tolsdorf ym., 2018; Kugelmass, 2001).

Luokittelu on ongelmallista myös tutkimuksellisesti: Luokitellessaan ja luokkia nimittäessään tutkijat myös tuottavat käsityksiä. Kun käsitteitä tuotetaan, niiden tulisi olla lähtökohtaisen inklusiivisen viitekehyksen mukaisia. Toisaalta asiasisällön jakamisen näkökulmasta käytettyjen käsitteiden tulisi olla ymmärrettävissä myös inklusiivisen viitekehyksen ulkopuolelta asiaa tarkasteleville. Tässä aineistossa opiskelijoiden tuottamat oppilaaseen liitetyt käsitykset pohjautuvat osin medikalistiseen ajatteluun ja tuen syy sijoitetaan oppilaaseen tai hänen ominaisuuksiinsa. Toisaalta käsitystä avartavat opiskelijoiden vastauksista ilmenevä käsitteiden moniulotteisuus sekä oppiaineeseen liitetyt näkökulmat. Opettajaopiskelijoiden edellä mainitut käsitykset tuen tarpeista ovat samankaltaisia kuin Kousan (2019) opettajia koskevassa tutkimuksessa.

Tuen tarpeita on tärkeää tutkia eri oppiaineiden opetuksen ja oppimisen konteksteissa, koska oppiaineet ovat luonteeltaan erilaisia - tuen tarpeiden ja tukimuotojen voidaan siis ajatella olevan erilaisia eri oppiaineissa. Eri oppiaineissa käytetyt opetusmenetelmät ja oppimisympäristöt sinänsä voivat tuottaa tukea inklusiivisessa koulussa. Opetuksen inklusiiviset lähtökohdat edellyttävät opettajaopiskelijoilta yhteistyö- ja verkostoitumisvalmiuksia viimeistään työelämässä. Tällöin opetusmenetelmät laajenevat kohti yhteisopettajuuden eri toteutustapoja (esim. Bešić, Paleczek, Krammer, \& Gasteiger-Klicpera, 2017) ja koulun arki laajemminkin muuttuu lasten kasvua eri tavoin tukevien ammattilaisverkostojen jakamaksi (Ben-Yehuda, Leyser, \& Last, 2010). Tämän vuoksi on tärkeää aloittaa eri opettajaryhmien keskinäinen yhteistyö jo opettajankoulutuksen aikana (ks. Malinen, Väisänen, \& Savolainen, 2012). 
Opettajankoulutuksen näkökulmasta olisikin tärkeää, että erityispedagoginen näkökulma ja inklusiivinen kouluajattelu ovat "diffuusisti" mukana opettajankoulutuksen opinnoissa (vrt. Sharma \& Sokal, 2015). Yksi keskeinen jatkotutkimusalue olisikin inkluusioperiaatteiden pedagoginen soveltaminen eri oppiaineiden opetuksessa ja opettajankoulutuksessa.

\section{Lähteet}

Ahtiainen, R., Lintuvuori, M., Hienonen, N., Jahnukainen, M. \& Hautamäki, J. (2017). Erityisten nimeäminen ja käsitteet perusopetuksessa - lyhyt historia ja nykytila. Teoksessa A. Toom, M. Rautiainen \& J. Tähtinen (toim.) Toiveet ja todellisuus: Kasvatus osallisuutta ja oppimista rakentamassa (ss. 119-142). Turku: Suomen kasvatustieteellinen seura.

Ainscow, M., Booth, T. \& Dyson, A. (2004). Understanding and developing inclusive practices in schools: a collaborative action research network. International Journal of Inclusive Education, 8(2), 125-139. https://doi.org/10.1080/1360311032000158015

Ainscow, M., Booth, T. \& Dyson, A. (2006). Improving schools, developing inclusion. London: Routledge.

Ainscow, M. \& Sandill, A. (2010). Developing inclusive education systems: the role of organisational cultures and leadership. International Journal of Inclusive Education, 14(4), 401-416. https://dx.doi.org/10.1080/13603110802504903

An, D. \& Carr. M. (2017). Learning styles theory fails to explain learning and achievement: Recommendations for alternative approaches. Personality and Individual Differences, 116, 410 -416. https://dx.doi.org/10.1016/j.paid.2017.04.050

Appelton, K. \& Kindt, I. (2002). Beginning Elementary Teachers' Development as Teachers of Science. Journal of Science Teacher Education, 13(1), 43-61.

https://dx.doi.org/10.1023/A\%3A1015181809961

Aronen, E.T., Vuontela, V., Steenari, M.-R., Salmi, J. \& Carlson, S. (2005). Working memory, psychiatric symptoms, and academic performance at school. Neurobiology of Learning and Memory, 83(1), 33-42. https://doi.org/10.1016/j.nlm.2004.06.010

Asghar, A., Sladeczek, I.E., Mercier, J. \& Beaudoin, E. (2017). Learning in Science, Technology, Engineering, and Mathematics: Supporting Students with Learning Disabilities. Canadian Psychology / Psychologie Canadienne, 58(3) 238-249.

https://dx.doi.org/10.1037/capooo0111

Avramidis, E. \& Norwich, B. (2002). Teachers' attitudes towards integration/inclusion: a review of the literature. European Journal of Special Needs Education, 17(2), 129-147. https://doi.org/10.1080/08856250210129056

Beacham, N. \& Rouse, M. (2012). Student-teachers' attitudes and beliefs about inclusion and inclusive setting. Journal of Research in Special Educational Needs, 12(1), 3-11. https://doi.org/10.1111/j.1471-3802.2010.01194.x

Ben-Yehuda, S., Leyser, Y. \& Last, U. (2010). Teacher educational beliefs and socio-metric status of special educational needs (SEN) students in inclusive classrooms. International Journal of Inclusive Education, 14(1), 17-34. https://doi.org/10.1080/13603110802327339

Bernelius, V. (2011). Osoitteenmukaisia oppimistuloksia? Kaupunkikoulujen eriytymisen vaikutus peruskoululaisten oppimistuloksiin Helsingissä. Yhteiskuntapolitiikka, 76, 479-493. 
Bešić, E., Paleczek, L., Krammer, M. \& Gasteiger-Klicpera, B. (2017). Inclusive practices at the teacher and class level: the experts' view. European Journal of Special Needs Education, 32(3), 329-345. https://doi.org/10.1080/08856257.2016.1240339

Brigham, F.J., Scruggs, T.E. \& Mastropieri, M.A. (2011). Science Education and Students with Learning Disabilities. Learning Disabilities Research \& Practice, 26(1), 223-232. https://doi.org/10.1111/j.1540-5826.2011.00343.x

Chao, C.N.G., Sze, W., Chow, E., Forlin, C. \& Ho, F.C. (2017). Improving teachers' self-efficacy applying teaching and learning strategies and classroom management to students with special education needs in Hong Kong. Teaching and Teacher Education, 66, 360-369. https://doi.org/10.1016/j.tate.2017.05.004

Doucerain, M. M., Dere, J. \& Ryder, A.G. (2013). Travels in hyper-diversity: Multiculturalism and the contextual assessment of acculturation. International Journal of Intercultural Relations, 37(6), 686-699. https://doi.org/10.1016/j.ijintrel.2013.09.007

European Agency for Special Needs and Inclusive Education, (2014). Five Key Messages for Inclusive Education. Putting Theory into Practice. Odense: European Agency for Special Needs and Inclusive Education.

Evagorou, M. \& Osborne, J. (2010). The role of language in the learning and teaching of science. Teoksessa J. Osborne \& J. Dillon (toim.) Good Practice in Science Teaching. What research has to say (ss. 135-157). London: McGraw-Hill.

Foley-Nipcon, M., Assouline, S.G. \& Colangelo, N. (2013). Twice-exceptional learners: Who needs to know what? Gifted Child Quarterly, 57, 169-180.

https://doi.org/10.1177/0016986213490021

Gilbert, A. \& Byers, C.C. (2017). Wonder as a tool to engage preservice elementary teachers in science learning and teaching. Science Education, 101(6), 907-928. https://doi.org/10.1002/sce.21300

Goethe, E.V. \& Colina, C.M. (2018). Taking Advantage of Diversity within the Classroom. Journal of Chemistry Education, 5, 189-192. https://doi.org/10.1021/acs.jchemed.7bo0510

Gorard, S. \& See, B.H. (2009). The impact of socio-economic status on participation and attainment in science. Studies in Science Education, 45(1), 93-129. https://doi.org/10.1080/03057260802681821

Greenfield, T. A. (1997). Gender- and grade-level differences in science interest and participation. Science Education, 81, 259-276. https://doi.org/10.1002/(SICI)1098237X(199706)81:3<259::AID-SCE1>3.0.CO;2-C

Hsieh, H.-F. \& Shannon, S.E. (2005). Three Approaches to Qualitative Content Analysis. Qualitative Health Research, 15, 1277-1288. https://doi.org/10.1177/1049732305276687

Itä-Suomen yliopisto (2016). Opinto-opas. Soveltavan kasvatustieteen ja opettajankoulutuksen osasto. Filosofinen tiedekunta. Joensuu: Itä-Suomen yliopisto.

Kiuppis, F. \& Hausstätter, R. (2014). Inclusive Education for All, and Especially for Some? On Different Interpretations of Who and What the "Salamanca Process" Concerns. Teoksessa F. Kiuppis \& R. Hausstätter (toim.) Inclusive Education Twenty Years after Salamanca (ss. 1-6). New York, NY: Peter Lang.

Kokkonen, T. \& Laherto, A. (2018). Tiedeopetuksen muuttuvat tavoitteet - sisältötiedosta luonnontieteelliseen lukutaitoon. Ainedidaktiikka, 2(1), 20-38. https://doi.org/10.23988/ad.69250

Kousa, P. (2019). Diversity and science teacher education: Supporting practices for better student achievement. Helsinki: University of Helsinki.

Kousa, P. \& Aksela, M. (2019). What is needed for successful chemistry teaching in diverse classes: teachers' beliefs and practices. LUMAT: International Journal on Math, Science and Technology Education, 7, 79-100. 
Krull, J., Wilbert, J. \& Hennemann, T. (2014). The social and emotional situation of first- graders with classroom behaviour problems and classroom learning difficulties in inclusive classes. Learning Disabilities: A Contemporary Journal, 12, 169-190.

Kugelmass, J.V. (2001). Collaboration and compromise in creating and sustaining an inclusive school. International Journal of Inclusive Education, 5(1), 47-65. https://doi.org/10.1080/13603110121498

Kupari, P., Vettenranta, J. \& Nissinen, K. (2012). Oppïjalähtöistä pedagogiikkaa etsimään. Kahdeksannen luokan oppilaiden matematiikan ja luonnontieteiden osaaminen. Kansainvälinen TIMMS-tutkimus Suomessa. Jyväskylä: Koulutuksen tutkimuslaitos.

Lambe, J. (2011). Pre-service education and attitudes towards inclusion: the role of the teacher educator within a permeated teaching model. International Journal of Inclusive Education, 15(9), 975-999. https://doi.org/10.1080/13603110903490705

Lee, O. \& Buxton, C.A. (2010). Diversity and Equity in Science Education. Research, Policy, and Practice. New York, NY: Teachers College Press.

Lee, O. \& Fradd, S.H. (1998). Science for All, Including Students from Non-English-Language Backgrounds. Educational Researcher, 27(4), 12-21.

https://doi.org/10.3102/0013189X027004012

Malinen, O.-P. \& Savolainen, H. (2016). The effect of perceived school climate and teacher efficacy in behavior management on job satisfaction and burnout: A longitudinal study. Teaching and Teacher Education, 6o, 144-152. https://doi.org/10.1016/j.tate.2016.08.012

Malinen, O.-P., Väisänen, P. \& Savolainen, H. (2012). Teacher education in Finland: a review of a national effort for preparing teachers for the future. The Curriculum Journal, 23(4), 567584. https://doi.org/10.1080/09585176.2012.731011

Mason, L.H. \& Hedin, L.R. (2011). Reading Science Text: Challenges for Students with Learning Disabilities and Considerations for Teachers. Learning Disabilities Research \& Practice, 26, 214-222. https://doi.org/10.1111/j.1540-5826.2011.00342.x

Mastropieri, M.A., Scruggs, T.E., Mantzicopoulos, P., Sturgeon, A., Goodwin, L. \& Chung, S. (1998). “A Place Where Living Things Affect and Depend on Each Other”: Qualitative and Quantitative Outcomes Associated with Inclusive Science Teaching. Science Education, 82, 163-179. https://doi.org/10.1002/(SICI)1098-237X(199804)82:2<163::AID$\mathrm{SCE} 3>3.0 . \mathrm{CO} ; 2-\mathrm{C}$

McCarthy, C.B. (2005). Effects of Thematic-Based, Hands-On Science Teaching versus a Textbook Approach for Students with Disabilities. Journal of Research in Science Teaching, 42, 245263. https://doi.org/10.1002/tea.20057

Messiou, K. \& Ainscow, M. (2020). Inclusive Inquiry: Student-teacher dialogue as a means of promoting inclusion in schools. British Educational Research Journal 46(3), 670-687. https://doi.org/10.1002/berj.3602

Moore, F. M. (2008). Preparing elementary preservice teachers for urban elementary science classrooms: Challenging cultural biases toward diverse students. Journal of Science Teacher Education, 19(1), 85-109. https://doi.org/10.1007/s10972-007-9083-2

Mulholland, J. \& Wallace J. (2001). Teacher induction and elementary science teaching: enhancing self-efficacy. Teaching and teacher education, 17(2), 243-261. https://doi.org/10.1016/S0742-051X(00)00054-8

Norman, K., Caseau, D. \& Stefanich, G.P. (1998). Teaching Students with Disabilities in Inclusive Science Classrooms: Survey Results. Science Education, 82(2), 127-146.

https://dx.doi.org/10.1002/(SICI)1098-237X(199804)82:2<127::AID-SCE1>3.0.CO;2-G

Opetushallitus (2014). Perusopetuksen opetussuunnitelman perusteet 2014. Helsinki: Opetushallitus. 
Osborne, J. \& Dillon, J. (2010). How science works. Teoksessa J. Osborne \& J. Dillon (toim.) Good Practice in Science Teaching. What research has to say (ss. 20-45). London: McGrawHill.

Pashler, H., McDaniel, M., Rohrer, D. \& Bjork, R. (2009). Learning Styles. Concepts and Evidence. Psychological Science in the Public Interest, 9(3), 105-119. https://doi.org/10.1111/j.15396053.2009.01038.x

Piliouras, P. \& Evangelou, O. (2012). Teachers' Inclusive Strategies to Accommodate 5th Grade Pupils' Crossing of Cultural Borders in Two Greek Multicultural Science Classrooms.

Research in Science Education, 42(2), 329-351. https://doi.org/10.1007/s11165-010-9198$\mathrm{X}$

Round, P.N., Subban, P.K. \& Sharma, U. (2016). 'I don't have time to be this busy.' Exploring the concerns of secondary school teachers towards inclusive education. International Journal of Inclusive Education, 2O(2), 185-198. https://doi.org/10.1080/13603116.2015.1079271

Savolainen, H., Engelbrecht, P., Nel, M. \& Malinen, O-P. (2012). Understanding teachers' attitudes and self-efficacy in inclusive education: implications for pre-service and in-service teacher education. European Journal of Special Needs Education, 27(1), 51-68. https://doi.org/10.1080/08856257.2011.613603

Schreier, M. (2014). Qualitative Content Analysis. Teoksessa U. Flick (toim.) The SAGE Handbook of Qualitative Data Analysis (ss. 170-183). Lontoo: SAGE.

Sharma, U., Forlin, C. \& Loreman, T. (2008). Impact of training on pre-service teachers' attitudes and concerns about inclusive education and sentiments about persons with disabilities. Disability \& Society, 23(7), 773-785. https://doi.org/10.1080/09687590802469271

Sharma, U. \& Sokal, L. (2015). The impact of a teacher education course on pre-service teachers' beliefs about inclusion: an international comparison. Journal of Research in Special Educational Needs, 15(4), 276-284. https://doi.org/10.1111/1471-3802.12043

Sikora, J. \& Pokropek, A. (2012). Gender Segregation of Adolescent Science Career Plans in 50 Countries. Science Education, 96, 234-264. https://doi.org/10.1002/sce.20479

Slee, R. (2001). 'Inclusion in Practice': does practice make perfect. Educational Review, 53(2), 113-123. https://doi.org/10.1080/00131910120055543

Smith, F.M. \& Hausafus, C.O. (1998). Relationship of Family Support and Ethnic Minority Students' Achievement in Science and Mathematics. Science Education, 82(1), 111-125. https://doi.org/10.1002/(SICI)1098-237X(199801)82:1\%3C111::AID-SCE6\%3E3.0.CO;2-K

Sormunen, K., Lavonen, J. \& Juuti, K. (2019). Overcoming Learning Difficulties with Smartphones in an Inclusive Primary Science Class. Journal of Education and Learning, 8(3), 21-34. https://doi.org/10.5539/jel.v8n3p21

Therrien, W.J., Taylor, J.C., Hosp, J.L., Kaldenberg, E.R., \& Gorsh J. (2011). Science Instruction for Students with Learning Disabilities: A Meta-Analysis. Learning Disabilities Research and Practice, 26(4), 188-203. https://doi.org/10.1111/j.1540-5826.2011.00340.x

Tolsdorf, Y., Kousa, P., Markic, S. \& Aksela, M. (2018). Learning to Teach at Heterogeneous and Diverse Chemistry Classes - Methods for University Teacher Training Course. EURASIA Journal of Mathematics, Science and Technology Education 14 (10), 1-14. https://doi.org/10.29333/ejmste/93377

Tutkimuseettinen neuvottelukunta. (2019). Ihmiseen kohdistuvan tutkimuksen eettiset periaatteet ja ihmistieteiden eettinen ennakkoarviointi Suomessa. Tutkimuseettisen neuvottelukunnan ohje 2019. Helsinki: Tutkimuseettinen neuvottelukunta.

UNESCO (2015). Incheon Declaration Education 2030: Towards inclusive and equitable quality education and lifelong learning for all.

http://www.unesco.org/new/fileadmin/MULTIMEDIA/HQ/ED/ED/pdf/FinalVersionIncheonDeclaration.pdf (Luettu 23.6.2018) 
Varcoe, L. \& Boyle, C. (2014). Pre-service primary teachers' attitudes towards inclusive education. Educational Psychology, 34(3), 323-337. https://doi.org/10.1080/01443410.2013.785061

Varelas, M., Kane, J. M. \& Wylie, C. D. (2011). Young African American children's representations of self, science and school: Making sense of difference. Science Education, 95(5), 824-851. https://doi.org/10.1002/sce.20447

Wassel, B.A., Kerrigan, M.R. \& Hawrylak, M.F. (2018). Teacher educators in a changing Spain: Examining beliefs of diversity in teacher preparation. Teaching and Teacher Education, 69(1), 223-233. https://doi.org/10.1016/j.tate.2017.10.004

Wellington, W., \& Wellington, J. (2002). Children with communication difficulties in mainstream science classrooms. School Science Review, 83(305), 81-92.

Velthuis, C., Fisser, P. \& Pieters, J. (2014). Teacher Training and Pre-service Primary Teachers' Self-Efficacy for Science Teaching. Journal of Science Teacher Education, 25(4), 445-464. https://doi.org/10.1007/s10972-013-9363-y

Vettenranta, J., Hiltunen, J., Nissinen, K., Puhakka, E., \& Rautopuro, J. (2016). Lapsuudesta eväät oppimiseen: neljännen luokan oppilaiden matematiikan ja luonnontieteiden osaaminen: kansainvälinen TIMSS-tutkimus Suomessa. Jyväskylä: Jyväskylän yliopisto, Koulutuksen tutkimuslaitos.

Vettenranta J., Välijärvi J., Ahonen A., Hautamäki J., Hiltunen J., Leino K., Lähteinen S., Nissinen K., Nissinen V., Puhakka E., Rautopuro, J., Vainikainen M.-P. (2016). PISA 2015 ensituloksia. Huipulla pudotuksesta huolimatta. Opetus- ja kulttuuriministeriön julkaisuja 2016:41. Helsinki: Opetus- ja kulttuuriministeriö.

Villanueva, M.G., Taylor, J., Therrien, W. \& Hand, B. (2012). Science education for students with special needs. Studies in Science Education, 48(2), 187-215.

https://doi.org/10.1080/14703297.2012.737117

Woodcock, S. \& Vialle, W. (2016). An examination of pre-service teachers' attributions for students with specific learning difficulties. Learning and Individual Differences, 45, 252-259. https://doi.org/10.1016/j.lindif.2015.12.021

Young, K., McNamara, P.M. \& Coughlan, B. (2017). Authentic inclusion-utopian thinking? - Irish post-primary teachers' perspectives of inclusive education. Teaching and Teacher Education, 68, 1-11. https://doi.org/10.1016/j.tate.2017.07.017

Zembylas, M. \& Isenbarger, L. (2002). Teaching Science to Students with Learning Disabilities: Subverting the Myths of Labelling Through Teachers' Caring and Enthusiasm. Research in Science Education, 32(55), 55-79. https://doi.org/10.1023/A:1015050706407 